\title{
DIE AARD, TOTSTANDKOMING EN ONTWIKKELINGSVERLOOP VAN DIE MILITÊRE SOSIOLOGIE MET VERWYSING NA ENKELE NAVORSINGSOORWEGINGS
}

\section{A. Senekal*}

The nature, coming into existence and developmental stages of Military Sociology is discussed in the article below with reference to the restrictions applicable to research in the field of Military Sociology. Military Sociology in the Republic of South Africa and a short perspective with reference to the future, are also included.

\section{Inleiding}

In hierdie bydrae word baie kortliks aan die volgende sake aandag gewy:

(a) Die aard van die Militêre Sosiologie oftewel ' $n$ antwoord op die vraag 'wat behels die Militêre Sosiologie?'.

(b) Die totstandkoming en ontwikkelingsverloop van die Militêre Sosiologie.

(c) Enkele beperkinge van toepassing op navorsing in die veld van die Militêre Sosiologie.

(d) Militêre Sosiologie in die R.S.A. en 'n kort toekomperspektief.

\section{Die aard van die Militêre Sosiologie}

Die aard van die Militêre Sosiologie word baie kortliks omlyn met verwysing na die volgende:

(a) Militêre Sosiologie as sub-area van die Sosiologie;

(b) Enkele definisies van die Militêre Sosiologie;

(c) Temas wat in hierdie veld die aandag geniet;

(d) Die verband tussen die Militêre Sosiologie en die Sosiologie van Oorlog.

Punte c en d sal gesamentlik bespreek word.

\subsection{Militêre Sosiologie as sub-area van die Sosiologie}

Die Sosiologie as wetenskap het as hooffokus een van die mees fundamentele sosiale prosesse te wete die proses van interaksie en wel soos hierdie proses hom in die verhouding tussen mense voltrek (Dressler, 1969:3).

Hierdie omskrywing van die hooffokus van studie in die Sosiologie kan misleidend eenvoudig voorkom en dit is daarom nodig om ook die volgende in gedagte te hou. Dit is naamlik dat hoewel sosiale of maatskaplike interaksie as hooffokus dien, dit nie uit die oog verloor moet word nie dat hierdie fundamentele proses enersyds ' $n$ omvattende proses is wat ' $n$ verskeidenheid verskyningsvorme van interaksie insluit en andersyds die grond- of basisproses vorm waarin talryke verdere prosesse en hierbenewens maatskaplike strukture, hul oorsprong vind.

Aldus gesien, begin dit duidelik word dat die studieterrein van die Sosiologie besonder omvattend is - veral ook as daaraan gedink word dat nie slegs die mees simplistiese van samelewings nie maar ook die mees komplekse samelewing in werklikheid 'gebore' oftewel sy oorsprong gevind het in die interaksie tussen mense en as sodanig deel vorm van die studieterrein van die Sosiologie.

In die lig hiervan verras dit dan ook nie dat daar mettertyd subareas in die Sosiologie begin uitkristalliseer het nie en dat Sosioloë hulle toenemend op geselekteerde subareas begin toelê het - gewoon omdat die studieveld van die Sosiologie in sy geheel onhanteerbaar omvangryk vir die enkeling begin word het. Hierdie onderverdeling van die Sosiologie kan aan die hand van verskeie kriteria geskied (Coates \& Pellegrin, 1965:9).

So byvoorbeeld kan die begripsmatige kriterium gebruik word in welke geval die aandag van die Sosioloog op subareas wat deur pertinente begrippe omlyn word, gefokus word. So 'n subarea is byvoorbeeld die van sosiale stratifikasie wat in verskillende kontekste die aandag van die Sosioloog kan beset - of dit nou in die konteks van 'n klein gemeenskap is of van die totale samelewing. 
Vervolgens kan van die ruimtelike of geografiese kriterium gebruik gemaak word. Soos die naam van die kriterium suggereer ressorteer alle subareas wat ' $n$ ruimtelike fokus het hieronder en is voorbeelde van sodanige areas die volgende: Landelike Sosiologie, Stedelike Sosiologie, Regionale Sosiologie en daardie areas in die Sosiologie wat die gemeenskap as hooffokus het.

'n Verder kriterium is die organisatoriese-d.w.s. daardie areas wat 'n organisatoriese opset as omlyning het. In hierdie verband kan na byvoorbeeld die Industriële Sosiologie en die Sosiologie van Groot Organisasies (burokrasieë) verwys word. Coates en Pellegrin plaas ook die bestudering van kleingroepe (klaarblyklik dus die groepsdinamika) hieronder. Let egter hier daarop dat kleingroepe nie slegs in 'n organisatoriese opset ontstaan en funksioneer nie, maar ook daarbuite ontstaan en bestudeer word.

' $n$ Volgende kriterium is die probleemgerigte kriterium d.w.s. die omlyning van subareas na aanleiding van die feit dat hierdie areas op gebiede fokus wat as probleemareas in die samelewing beskou word. Op grond hiervan kan die bestudering van Maatskaplike Probleme onderskei word waaronder, volgens Coates en Pellegrin, ook die volgende ressorteer: Afwykende Gedrag, Kriminologie, Penologie, en Jeugmisdaad.

'n Laaste kriterium is die institusionele waarvolgens komplekse van verbandhoudende instellings as subareas beskou en bestudeer word. Hieronder sou Gesins-, Opvoedkundige-, Ekonomiese- en Politieke Sosiologie ressorteer. Coates en Pellegrin noem ook ander institusionele opsette wat as hooffokus van subareas dien: gesondheid, medisyne, wetenskap, vermaak en die estetiese. Militêre Sosiologie, omdat dit as hooffokus militêre instellings het, ressorteer volgens Coates en Pellegrin as institusionele subarea in die breë veld van die Sosiologie. Hierdie is dan ook die sienswyse wat in die bespreking gehuldig word.

In 1956 egter sê Charles Hutchinson die volgende. Hy beweer naamlik dat daar weinig regverdiging vir die Militêre Sosiologie as subarea van die Sosiologie bestaan en mak dan die enigsins naïewe stelling dat die enigste onderskeidende aspek van die Militêre Sosiologie die feit is dat dit slegs op militêre populasies van toepassing is, deur militêre organisasies gesteun word en gebruik word vir die oplossing van militêre probleme. Self stel hy dit soos volg: 'There is less justification for the designation of an area of sociological research and teaching interest as military sociology than there is for the creation of specialty such as industrial sociology. The reason for this is the fact that military sociology is an almost complete cross section of sociology and social psychology. The only distinctive aspect of military sociology is its application to military populations, its support by military organizations, and its use in solving military problems'. (1956-57:427).

'n Verdere punt van kritiek wat teen Hutchinson ingebring kan word is die ongeldigheid van die rede wat hy aanvoer ter ondersteuning van sy standpunt: 'The reason for this is the fact that military sociology is an almost complete cross section of sociology and social psychology' (1956-57:427) Word gekyk na Industriële Sosiologie - 'n subgebied van die Sosiologie waarna Hutchinson self verwys maar die bestaansreg waarvan oënskynlik nie deur hom bevraagteken word nie - word gevind dat die industrie of bedryf nie bestudeer kan word sonder inagneming van die politieke, ekonomiese, godsdienstige, opvoedkundige en ander dimensies daarvan nie. Aldus word noodwendig gebruik gemaak van insigte en metodes vanuit die politieke-, ekonomiese-, godsdiens- en opvoedkundige sosiologie. Vanuit sosiaal-sielkundige perspektief is groepsdinamiese kennis en tegnieke voorts 'n integrale deel van die begrip vir bestuur en suksesvolle funksionering van die bedryf. Só gesien sou dus ook van die Industriële Sosiologie trouens van alle spesialiseringsgebiede in die Sosiologie - gesê kon word dat dit ' $n$ ' ... almost complete cross section of sociology and social psychology ...' verteenwoordig. Nogtans bring dit nie die bestaansreg van enige van die ander spesialiseringsgebiede in die gedrang nie. Waarom sou dit dan net op die Militêre Sosiologie van toepassing wees?

Ten slotte is die bestaansreg vir ' $n$ subgebied in die Sosiologie primêr gesetel daarin dat die verskynsel of proses wat bestudeer word

(a) 'n dominante sosiale of maatskaplike dimensie moet bevat

(b) van besondere belang en relevansie vir die sameleweing moet wees

(c) 'n omvang moet hê wat 'n betekenisvolle deel van die bevolking raak

(d) ' $n$ intensiteit moet besit wat moeilik deur die lede van die samelewing geïgnoreer kan word.

Aan al hierdie vereistes voldoen die militêre sisteem par excellence. 
Uit die voorafgaande is dit belangrik om die volgende twee aangeleenthede opsommend uit te lig:

Eerstens - die omvattende aard vand ie sosiologiese studieterrein en die belangrikheid van militêre aangeleenthede in die moderne samelewing noodsaak nie alleen nie, maar regverdig 'n wetenskaplike bestudering van spesifiek die militêre tema as sub-area van die Sosiologie.

Tweedens - die institusionele aard van die militêre tema plaas die fokus van hierdie studiegebied nie slegs op die weermag (as kollektiwiteit) van 'n samelewing nie, maar op die meer omvattende militêre sisteem (as instelling of institusionele subsisteem) vandie samelewing.

\subsection{Enkele definisies van die Militêre Sosiologie}

Sonder om 'n grondige uiteensetting te gee van die voor- en/of nadele van ' $n$ bepaalde definisie of definisies, word kortliks gekyk na drie definisies van die Militêre Sosiologie te wete die van Lang, Janowitz en Coates en Pellegrin.

Kurtz Lang het buitengewoon omvattende en belangrike werk in die Militêre Sosiologie gelwer en wel in die vorm van geannoteerde bibliografiese publikasies waarin ook telkens ' $n$ oorsig van die Militêre Sosiologie gegee is. Aldus het hy ' $n$ besondere bydrae gelewer in die omlyning van die veld van die Militêre Sosiologie.

In al sy publikasies lê Lang, na aanleiding van Lasswell se definisie van militêre instellings, besonder klem op die element van georganiseerde geweld as sentrale faktor in die studiegebied van die Militêre Sosiologie. In 1965 laat hy hom as volg uit oor die Militêre Sosiologie:

'Within the province of military sociology lie all those structures and situations where the employment of organized violence or armed force enters as a primary consideration, either as a means or as an obstacle, in the pursuit of some social objective. The criterion of 'violent means' delineates military sociology from a general sociology of conflict, whereas the criterion of 'organization' excludes sporadic outbreaks of violence and turns attention to the more permanent structures by which superior force is carefully mustered for the eventuality that its use may prove indispensable or unavoidable' (1965:5-6).

In 1970 maak hy van min of meer dieselfde definisie gebruik en so ook in sy 1972 publikasie waar hy sy definisie as volg formuleer: 'The sub- ject matter of military sociology is best defined by reference to organized violence. All those situations and structures in which this element constitutes a major and legitimate preoccupation - whether as a readily available means to achieve some social objective or as a potential last resort - are within its scope' (Lang, 1972:9). Hy kwalifiseer egter hierdie definisie enigsins anders as in 1965 deurdat hy die aandag op die volgende vestig: 'The criterion of 'violent means' places the field of military sociology within a more inclusive sociology of conflict, but sporadic outbursts of violence and conflict between individuals or groups insofar as the element of organization is lacking are not military phenomena. For intergroup violence to assume a military character, the claims of both parties in a conflict to belligerent status must be at least tacitly recognized by one another. Accordingly military sociology focuses on the permanent structures indispensable to the conduct of organized warfare' (Lang, 1972:9-10).

Waar Lang in sy 1965 definisie Militêre Sosiologie ten opsigte van die Sosiologie van Konflik skynbaar eenkant wou plaas, plaas hy dit in sy 1972 definisie baie eksplisiet binne die grense van hierdie veld. Voorts knoop hy die Militêre Sosiologie ook meer eksplisiet as vroeër aan daardie permanente strukture wat ' $n$ ononbeerlike rol te speel het in die voer van georganiseerde oorlog.

Morris Janowitz sien weer die Militêre Sosiologie soos volg: 'The sociological analysis of the military cannot be contained or restrained by arbitrary institutional categories. In a period of rapid social and political change the focus of attention must of necessity include the full range of institutions which deal with force and violence' (in Van Doorn, 1968:15-16). Omdat die koste verbonde aan die oorlog in die kontemporêre situasie besonder hoog geword het - in so 'n mate dat selfs die militêre professie begin besef dat oorlog nie noodwendig in die nasionele belang is nie meen Janowitz dat die Militêre Sosiologie ook aandag moet gee aan internasionale wapenbeheer en ontwapening, multilaterale reëlings en VN vredesaktiwiteite. Ook omdat 'beperkte' oorloë vandag meer algemeen voorkom en nie-professionele magte hierdeur betrek word, moet die Militêre Sosiologie noodwendig ook kyk na gewapende revolusies, polisie sisteme, opstande, paramilitêre eenhede e.a. agente van interne oorlogvoering. In sy eie woorde omskryf Janowitz die voorafgaande as volg: ' . .. the study of the military profession involves its reaction to the 
actual and proposed international schemes of arms control and disarmament. The sociology of the military must also encompass the consequences of multi-lateral arrangements and United Nations peace keeping activities which are designed to contain or reduce limited wars, especially those limited wars which might increase the possibility of general war' (in Van Doorn, 1968:16). Verwysende na beperkte oorloë sệ hy: 'These struggles involve use of nonprofessional forces, and therefore, the study of militarism and violence involves the analysis of various forms of armed revolts, police systems, insurrections, paramilitary formations and the other agencies of internal warfare' (in Van Doorn, 1968:16).

Ten slotte word gelet op die definisie van Coates en Pellegrin. Volgens hulle is die Militêre Sosiologie daardie onderafdeling vandie ouer dissipline wat die sosiologiese perspektief gebruik in die bestudering van sy studie-objek, te wete militêre aangeleenthede van ' $n$ institusionele aard. Militêre aangeleenthede van hierdie aard verwys na 'n georganiseerde sisteem van aktiwiteit - oftewel georganiseerde geweld in Lasswell se terme - gerig op die bereiking van sekere doelstellings soos die uitoefening van aggressie teen ander samelewings, die beskerming van die eie samelewing teen aggressie deur ander en die verskaffing van middele vir die handhawing van binnelandse orde en beheer met behulp van militêre instansies soos die leër, lugmag en vloot. Self stel hulle dit so: 'The content of the field consists of those military topics to which attention is directed by sociological concepts. The military setting or environment is the focus of study ... military affairs in a society can be regarded as an organized system of activity directed at the achievement of certain goals. Thus viewed, military institutions are organized activities for carrying on aggression against other societies, protecting the society against aggression by others, and providing the means for maintaining domestic order and control. Military institutions include all agencies devoted to such ends, such as armies, navies, and air forces... The term ('military institutions') is similar in meaning to two terms in popular usage, the 'armed forces' and the 'military establishment' (Coates \& Pellegrin, 1965:9-10).

Vanweë die vereniging van sosiaal-wetenskaplike en suiwer militêre oorwegings in hul definisie, word die definisie van Coates en Pellegrin as die mees geskikte aanvaar.

\subsection{Temas wat in die veld van die Militêre Sosiologie die aandag geniet en die verband tussen die Militêre Sosiologie en die Sosiologie van Oorlog.}

Op grond van veral sy uitgebreide bibliografiese werk in die Militêre Sosiologie is die literatuur in hierdie veld volgens Lang (1972) in die volgende tematiese kategorieë verdeelbaar. Die kategorieë word hier bloot genoem:

(a) Die militêre professie

Onder hierdie hooftema onderskei Lang die volgende subtemas:

- Professionalisering

- Rekrutering

- Betrokkenheid en assimilasie

- Beroepsmobiliteit

- Ideologie en selfbeeld

(b) Organisatoriese aspekte

Sub-temas wat hier die aandag geniet, is die volgende:

- Militêr-siviele vergelykings

- Outoriteit en diskresie

- Groepsnorme en leierskap

- Kohesie onder spanning

- Sosiale disorganisasie

(c) Die militêre sisteem

Hieronder ressorteer die volgende:

- Militêre deelname

- Mannekragvereistes

- Funksies

(d) Siviel-militêre verhoudings

- Normatiewe invloede van die militêre sisteem op die res van die samelewing

- Die beleidsproses

- Militêre intervensie

(e) Oorlog en oorlogvoering

- Gevolge en funksies

- Die oorsake van oorlog

- Die voering van oorlog

Enkele opmerkings in verband met Lang se indeling van die verskynsel van oorlog en oorlogvoering as deel van die Militêre Sosiologie, is hier nodig.

Alhoewel 'n paar vroeë sosioloë, veral Sosiale Darwiniste (bv. Sumner en Gumplowicz), hulle besig gehou het met die rol van oorlog in die evolusie van groepe en samelewings (Walter, 1958:656-658) en Lang (1965:6) die Sosiologie van Oorlog as een van die vier studiegebiede van die Militêre Sosiologie beskou, is Hutchinson (1956-57:427) die mening toegedaan dat Militêre Sosiologie nie nou verwant is aan die Sosiologie van Oorlog nie en verduidelik dit as volg: 'Fortunately, it is not necessary for the military sociologist to resolve these different points of 
view, (d.i. verskillende pogings in die Sosiologie van Oorlog om oorlog as verskynsel in menslike gedrag te verklaar) although he is likely to have given them some consideration in weighing his own personal and professional values in getting involved in the field of military sociology'. Ook Roucek (1962:29) in sy bespreking van die Sosiologie van Oorlog is by implikasie van mening dat hierdie studiegebied enigsins losstaan van die Militêre Sosiologie: '... numerous valuable sections and passages can be found therein (the voluminous literature on war) which actually concern themselves, strictly speaking, with the field of Military Sosiology'.

Wat die verband tussen die Militêre Sosiologie en die Sosiologie van Oorlog betref, word die volgende standpunt hier daarop nagehou: Anders as in Hutchinson se geval, word die Militêre Sosiologie en die Sosiologie van Oorlog, vanweë die raakpunte wat daar noodwendig tussen hierdie gebiede sal bestaan en soos Roucek daarop gewys het, as twee aanverwante maar definitief onderskeibare studiegebiede van die Sosiologie beskou.

As sodanig word die bestudering van die verskynsel van oorlog per se nie as legitieme taak of funksie van die Militêre Sosiologie beskou nie maar eerder as taak van die Sosiologie van Oorlog. ${ }^{1}$ Hiermee word egter nie te kenne gegee dat oorlog en die bestuderig daarvan totaal verwyderd staan van die Militêre Sosiologie nie maar wel dat die verskynsel van oorlog in 'n gekwalifiseerde sin die aandag van die Militêre Sosiologie verdien. Die kwalifikasie lê daarin dat die Militêre Sosiologie hom met oorlog bemoei alleenlik vir sover hierdie verskynsel die konteks vorm binne die raamwerk waarvan die militêre sisteem sy oorsprong, bestaansregverdiging en toepassingswaarde vind.

\section{Die totstandkoming en ontwikkelingsverloop van die militêre sosiologie}

In die behandeling van ' $n$ tema soos die bogenoemde is dit moontlik om ' $n$ uitvoerige uiteensetting te gee van die werk van die heel vroegste sosioloë en sosiale-filosowe wat hulle besig gehou het met die verskynsels van konflik en oorlog, om hierdeur die historiese wortels en uiteindelike ontstaan van die Militêre Sosiologie as sub-area van die Sosiologie te probeer aandui. ' $n$ Uiteensetting van hierdie aard kan besonder omvangryk wees en wel in so ' $n$ mate dat
A.W. van den Aardweg in 1971 'n substansiële deel van sy magister verhandeling getiteld The Origin, Development and Field of Military Sociology hieraan gewy het.

In hierdie bespreking word dan baie kortliks gelet op die oorsprong en ontwikkeling van die Militêre Sosiologie, nie deur die historiese wortels daarvan te probeer uitlig nie, maar eerder deur te konsentreer op veral die ontwikkeling van die Militëre Sosiologie nadat hierdie studiegebied reeds die naam Militêre Sosiologie verwerf het en as sodanig die militêre as legitieme studieprojek vir homself toegeëien het. Vrae wat dus hieruit na vore tree is die volgende: Wanneer, en waar het die Militêre Sosiologie sy oorsprong gehad en watter ontwikkelingsverloop het dit sedert die ontstaan daarvan vertoon?

Wat die eerste vraag betref is dit so dat dit normaalweg moeilik is om die oorsprong of ontstaan van ' $n$ bepaalde studiegebied te identifiseer. Tog is die geval met Militêre Sosiologie anders en is verskeie outeurs dit met mekaar eens dat die Tweede Wêreldoorlog ${ }^{2}$, ook die totstandkoming van die Militêre Sosiologie as studiegebied - aanvanklik weliswaar met ' $n$ meer toegepaste sosiaal-wetenskaplike oriëntasie - beteken het. (Coates en Pellengrin, 1965:10; Hutchinson, 1956-57:429; Kourvetans en Dobratz, 1976:68; Roucek en Lottich, 1964:103; Lang, 1972:19 en Hall, 1956:59). In antwoord op die tweede vraag kan hierdie ook as die inisiëringspunt in die ontwikkelingsverloop van die Militêre Sosiologie beskou word. Met die nasionale mobilisering gedurende WO II in die V.S.A., het troepe probleme op die gebiede van moreel, motivering en aanpassing by die militêre lewenswyse ondervind. In die lig hiervan het die Inligtings en Opvoedingsafdeling van die Amerikaanse Leër ('Information and Education Division of the Army') in 1941 die sogenaamde Navorsingstak ${ }^{3}$ ('Research Branch') in die lewe geroep met die oog daarop om 'n studie te maak van die moreel en motivering van die gewapende magte (Coates en Pellengrin, 1965:10). Hierdie program het op ' $n$ voltydse indiensbasis van talle uitstaande gekwalifiseerde sosioloë ${ }^{4}$ en sosiaal-sielkundiges gebruikgemaak in die bestudering van laasgenoemde sosiaal-sielkundige probleme met die oog daarop om 'n verligting of oplossing in hierdie verband te fasiliteer en aldus die effektiwiteit van die militêre masjien te verhoog (Kourvetaris en Dobratz, 1976:68 en Hutchinson, 1956-57:429).

Groot dele van hierdie navorsing is in 1949 weer- 
gegee deur Samuel Stouffer en sy mede outeurs in 'n vier-volume werk getiteld Studies in Social Psychology in World War II. Die eerste twee volumes, bekend as The American Soldier met die subtitel van volume I Adjustment During Army Life en dié van volume II Combat and its Aftermath sentreer hoofsaaklik om ' $n$ analise van aanpassing by die militêre lewe en reaksies op gevegte en op die staking van vyandelikhede (Coates en Pellengrin, 1965:10-11). Volume drie en vier wat onderskeidelik fokus op die effek van massakommunikasie media en metodologiese aspekte is getiteld: Experiments on Mass Communication en Measurement and Prediction (Van den Aardweg, 1971:82-83). Die belangrikheid van hierdie studies blyk uit die woorde van Lang (1965:3) '... the volumes of The American Soldier ... contain data on the effectiveness of training methods, on problems of adjustment and morale, and on combat performance that no subsequent researcher could possibly ignore'. Dit kan tereg dan ook beweer word dat hierdie as die eerste belangrike werk in die Militêre Sosiologie beskou kan word (Kourvetaris en Dobratz, 1976:69).

Werk soortgelyk aan die bogenoemde maar op ' $n$ kleiner skaal en ietwat meer sielkundig in oriëntasie, is deur die Tavistock Institute in Britanje gedurende die Tweede Wêreldoorlog gedoen (Lang, 1972:19).

In 1950 verskyn daar na aanleiding van 'n retrospektiewe analise van die American Soldier 'n ewe belangrike studie te wete dié deur Robert K. Merton en Paul S. Lazarsfeld getiteld Continuities in Social Research: Studies in the Scope and Method of the American Soldier. Free Press, New York. Hierin word die teoretiese en metodologiese implikasies van die American Soldier, veral soos betrekking het op primêre groepe, relatiewe deprivasie, verwysingsgroepteorie en toegepaste navorsing, bespreek (Kourvetaris en Dobratz, 1976:10).

Direk na WO II beskryf sosioloë wat militêre diens verrig het of betrokke was by navorsing, hul ervaringe in hierdie konteks wat betref belangrike sosiologiese aangeleenthede in die 1946 uitgawe van die American Journal of Sociology wat in sy geheel aan artikels van hierdie aard gewy is en soos volg getiteld is: Human Behaviour in Military Society. Aangeleenthede van die bogenoemde aard wat hierin aandag geniet is o.a. burokratiese aspekte, stratifikasie patrone en outoritêre metodes van maatskaplike beheer in die militêre organisasie (Kourvetaris en
Dobratz, 1976:70). 'n Publikasie wat in min of meer dieselfde tydperk verskyn het en volgens Lang die status van 'n klassieke sosiologiese werk verwerf het, is die 1948 artikel deur A.E. Shils en M. Janowitz getiteld 'Cohesion and Disintegration of the Wehrmacht in World War II' in die Public Opinion Quarterly, Vol. 12, 1948, pp 280-315. Hierin evalueer Shils en Janowitz die relatiewe belangrikheid van interpersoonlike, organisatoriese en ideologiese faktore in die weerstand van die Duitse Leër gedurende WO II (Lang, 1965:3).

Die ontwikkeling van die Militêre Sosiologie tot op hierdie punt blyk grootliks gekondisioneer te gewees het deur eksterne faktore soos die Tweede Wêreldoorlog en die probleme wat die Amerikaanse Leër gedurende die nasionale mobilisasie in hierdie tydperk ondervind het. In die lig hiervan kan dus nie met reg beweer word dat die Militêre Sosiologie op hierdie stadium van sy ontwikkeling reeds ' $n$ inherente dinamika of outonomiteit ontwikkel het waardeur hierdie gebied vanuit sigself verder sou kon ontwikkel nie. Hiermee in gedagte word dit dan ook nie as ongeregverdigd beskou om, wat hier as die eerste ontwikkelingsfase van die Militêre Sosiologie beskou word, die pre-outonome fase in die ontwikkeling van die Militêre Sosiologie te noem nie.

'n Tweede ontwikkelingsfase wat hier as die oorgangsfase beskryf sal word, kan ook onderskei word.

Tydens hierdie fase het die afhanklikheid van die Militêre Sosiologie soos in die pre-outonome fase na vore getree het, enigsins voortgeduur maar soos kenmerkend van alle oorgange van een fase tot ' $n$ volgende, nie sonder ernstige spanninge en stremminge vir die betrokke partye nie.

Soos Coates en Pellengrin (1965:11) daarop wys het die Departement van Verdediging in die V.S.A. en verskeie vertakkinge van die Gewapende Magte sedert 1950 voortgegaan met studies van ' $n$ sosiologiese en sosiaal-sielkundige aard en hierbenewens soortgelyke navorsing deur buite organisasies (veral universiteite) en individue geborg. Dit is dan ook veral binne die konteks van geborgte navorsing van hierdie aard dat die genoemde spanninge en stremminge hul oorsprong gehad het.

Janowitz en Little (1974:15) wys daarop dat die spanning tussen akademiese sosiaal-wetenskaplikes en die militêre, progressief na die 
einde van die Tweede Wêreldoorlog toegeneem het as gevolg van enersyds administratiewe konflikte en andersyds dieperwordende politieke en ideologiese verskille. Met die Koreaanse oorlog waartydens 'n gedeeltelike mobilisasie gegeld het, kan die militêre nie daarin slaag om die mees effektiewe siviele talent betrokke te kry nie. Daar was ook 'n onsuksesvolle poging om 'n meer permanente staf van sosiaal-wetenskaplikes te skep. Hierbenewens het die organisatoriese struktuur van die militêre, tot ' $n$ baie groter mate as gedurende WO II, beperkinge op sosiaal-wetenskaplike navorsing geplaas. Tog het daar in ' $n$ mate relevante dataversameling plaasgevind wat later tot betekenisvolle publikasie insake rasseverhoudings in die V.S.A. magte, die moreel van die kommunistiese magte en die gedrag van Amerikaanse krygsgevangenis gelei het. So byvoorbeeld het die navorsing deur Albert Biderman soos in sy werk The Road to Calumny, Macmillan, New York, 1963, vervat, belangrike stereotipes van hoe V.S.A. troepe in gevangenisskap opgetree het en soos deur die massa media voorgehou, gekorrigeer (Janowitz en Little, 1974:15-16).

In die periode ná die Koreaanse Oorlog het die status van akademiese navorsing oor militêre instellings en die verhoudings tussen universitêre sosiaal-wetenskaplikes en die militêre instelling ' $n$ kritieke drempel bereik. Enersyds is hierdie swak verhoudings teweeggebring deur die wydverspreide politieke weerstand op universiteitskampusse teen die Vietnam Oorlog, as gevolg waarvan regeringsgeborgte navorsing vir kritiek uitgesonder is en verskeie prominente professore wat die oorlog in Vietnam gesteun het en betrokke was by konsultasie of navorsing, as teikens vir protes uitgekies is (Janowitz en Little, 1974:16). Andersyds is spanning gewek deur die afwesigheid van effektiewe norme wat die verhouding tussen navorsingspersoneel van universiteite en regeringsbronne van finansiering kon reguleer. Die uitvloeisel hiervan was dat die regering geheime navorsing deur universiteite geborg het en universiteite gefouteer het deur sodanige navorsing - wat nie te versoen is met die doelstellings van siviele universiteite nie (bv. die beoefening van navorsing en die publikasie van resultate in ' $n$ akademies vrye klimaat) - te aanvaar. Vergetyk in hierdie verband die Projek. 'Camelot' (Janowitz en Little, 1974:16-17).

Gedurende die Vietnam Oorlog onderneem die militêre amptenare self sosiaal-wetenskaplike data-versamelingsprojekte, enersyds vanweë die genoemde weerstand teen die Vietnam Oor- log en andersyds vanweë die feit dat groot dele van die navorsing in verband met Vietnam-operasies wat deur die militêre geborg is, baie moeilik, indien enigsins, te versoen was met die doelstellings en prosedures van die siviele universiteit. Tog het enkele professioneel verantwoordelike studente soos Charles Moskos, wat homself as 'n koerant korrespondent laat akkrediteer het, veldnavorsing in Vietnam gedoen (Janowitz en Little, 1974:18).

Enkele verdere werke van belang wat gedurende hierdie stormagtige fase verskyn het en aldus ' $n$ bydrae tot die ontwikkeling van die Militêre Sosiologie gelewer het, is die volgende:

Special Order and the Risks of War (1952) deur Speier met ' $n$ verskeidenheid van artikels wat met die Militêre Sosiologie in verband staan; die werk van die politieke wetenskaplike Huntington, The Soldier and the State (1957) waarin, in terme van ' $n$ historiese raamwerk, die eerste belangrike behandeling van siviele-militêre verhoudings as 'n afsonderlike kategorie van politieke verskynsels, voorkom (Kourvetaris en Dobratz, 1976:70).

Met as uitvloeisel van al die voorafgaande gebeure $\mathrm{nl}$. dat enige sosiaal-wetenskaplike navorsing oor militêre aangeleenthede - ongeag die borgskap daarvan - gedurende die tweede helfte van die sestigerjare wydverspreid aangeval is (Janowitz en Little, 1974:18) loop hierdie stormagtige oorgangsfase ten einde.

Indien die afhanklikheid van navorsing oor militêre aangeleenthede, wat soveel bygedra het to bogenoemde stremminge, sou voortduur, sou Militêre Sosiologie volgens Lang omskep gewees het in ' $n$ Koue Oorlog dissipline (Lang, 1970:9). Hy wys voorts egter daarop dat daar juis gedurende hierdie periode geleidelik outonome forums op die voorgrond begin tree het in diens van almal - binne en buite die militêre wat in die onderwerp geînteresseerd was (Lang, 1970:9). Hierdie neiging, wat in wese die derde ontwikkelingsfase van die Militêre Sosiologie, of soos dit hier genoem gaan word, die outonome fase ingelei het, word baie treffend soos volg deur Janowitz en Little beskryf: 'This dominant trend of tension and incomplete professional responsibility was predictably accompanied by a more circumscribed but persistent countertrend. The publication of Sociology and the Military Establishment in 1959 signaled (sic) the fact that there was a group of social scientists who, regardless of their policy outlook, wished to pursue research on military institutions on a scholarly basis and with professional responsibility. They 
believed that it was essential to continue intellectually objective analysis of military institutions and their impact on U.S. society and to make their findings available in scholarly publications. Through the years of confrontation and disruption of academic life, these social scientists were able to press forward with their research. On the basis of collegial support, they succeeded in maintaining and even expanding academic teaching and research on these vital issues.

They relied mainly on their own labor power and some limited foundation support during the years of tension about government sponsored research' (1974:18-19).

Die noodsaaklikheid van en behoefte aan 'n forum waar sosioloë, geïnteresseerd in navorsing oor die militêre, in 'n nie-militêre opset kon ontmoet, vind dan ook in die middel vyftigerjare onder voorsitterskap van Morris Janowitz konkreet vergestalting in die skepping van die 'InterUniversity Seminar on Military Organization' by die Universiteit van Michigan. Die navorsing vervat in The New Military, Russel Sage Foudation, New York, 1964 onder redaksie van Morris Janowit $z^{5}$ gee 'n aanduiding van die spektrum van belangstelling onder betrokkenes by die forum. Die naam van die seminaar is later verander na die 'Inter-University Seminar on Armed Forces and Society'6 (Lang, 1972:23). Aanvanklik het hierdie forum slegs bestaan uit ' $n$ paar Amerikaanse Sosioloë wat gereeld onder voorsitterskap van Janowitz vergader het. Teen die middel-sestigerjare egter het hierdie nukleus uitgebrei om lede van ander nasionaliteite in te sluit terwyl ' $n$ deel van hierdie groep opgeneem is in ' $n$ Werkgroep van die Internasionale Sosiologiese Vereniging met as studie-objek Gewapende Magte en die Samelewing ${ }^{7}$ (Working Group on Armed Forces and Society of the International Sociological Association) (Lang, 1970:10).

Ten spyte van die struikelblokke wat bestaan in die internasionale studie van militêre instellings, het die hierbogenoemde Werkgroep van die Internasionale Sosiologiese Vereniging of soos Janowitz en Little daarna verwys, 'The Research Committee on Armed Forces and Society' buitengewoon presteer op byvoorbeeld die gebied van vergelykende navorsing en internasionale byeenkomste. Drie sodanige byeenkomste in die vorm van internasionale konferensies wat reeds gehou is, is die volgende: London (Julie 1964 en September 1967), Evian, Frankryk (September 1966) en Varna (September 1970). As uitvloeisel hiervan sien ' $n$ reeks van spesiale internasionale publikasies de lig. ${ }^{8}$

Van die publikasies wat direk of indirek deur die 'Inter-University Seminar' die lig gesien het, word hier ' $n$ paar genoem. Roger Little byvoorbeeld ontvang opdrag van die Seminaar om 'n oorsig van navorsingstendense te gee en hy tree dan as redakteur op van Handbook of Military Institutions, Beverly Hills, Sage Publications, 1971. Kurt Lang laat in 1972 'n bibliografiese oorsig van die literatuur die lig sien. Sy werk is getiteld: Military Institutions and the Sociology of War, Beverly Hills, Sage Publications, 1972.

Navorsing deur die 'Inter-University Seminar' het geleidelik ' $n$ toenemend interdissiplinêre kleur gekry terwyl die toename in navorsing en wetenskaplike skrywery in ' $n$ reeks verdere publikasies na vore getree het. ${ }^{9}$ 'n Aantal artikels het ook reeds in verskeie tydskrifte verskyn insluitende spesiale uitgawes van die Pacific Sociological Review (April, 1973) die Annals of American Academy of Political and Military Sociology (March, 1973). Hierbenewens het die 'Inter-University Seminar' ook twee nuwe tydskrifte geïnisieer te wete die Journal of Political and Military Sociology (Spring, 1973) en Armed Forces and Society (Fall, 1974) (Kourvetaris en Dobratz, 1976:71).

Bykomend tot die 'Inter-University Seminar' en die 'Working Group on Armed Forces and Society of the International Sosiological Association' is daar volgens Lang (1970:10) verdere aanduidings van die toenemende aanvaarding daarvan dat militêre aangeleenthede die aandag van Sosioloë verdien. Waar hy byvoorbeeld in 1965 (p.5) daarop wys dat die eerste handboek in Militêre Sosiologie nog gepubliseer moet word, vestig hy in 1970 (p.10) die aandag daarop dat reeds twee sodanige publikasies die lig gesien het: Coates, C.H. en Pellengrin, R.J.: Military Sociology: A Study of American Military Institutions and Military Life, Maryland Book Exchange, College Park, 1965; Wiatr, J.J.: Socjologia wojska (Military Sociology), Wydawnictwo Ministerstwa Obrony Narodowej, Warszawa, 1964. In sy bibliografie verwys Lang egter na 'n derde handboek, ook deur laasgenoemde outeur en waarskynlik 'n hersiene uitgawe van die voorgenoemde: Wiatr, J.J.: Armia i spoleczénstwo : wprowadzenie do socjologii wojska (Army and Society: An Introduction to Military Sociology). Wydawnicto Ministerstwa Obrony Narodowej. Warszawa, 1960. Lang gaan voort deur daarop te wys dat die verskeie kompen- 
dia $^{10}$ van sosiologiese teorie of navorsing meer geneig is om bydraes in verband met die militêre as organisasie of as institusionele subsisteem, vergelykbaar met dié van die industrie, opvoeding, wet of godsdiens, in te sluit (1970:10). Voorts is twee belangrike sosiologie tydskrifte ${ }^{11}$ in hierdie tyd aan die Militêre Sosiologie gewy terwyl Janowitz, M. en Little, R. se werk Sociology and the Military Establishment wat vir die eerste maal in 1959 gepubliseer is, in 1965 'n hersiene uitgawe beleef (1970:10)

Dat die strewe waarvan die voorafgaande tekenend is, vrugte afgewerp het en waarskynlik selfs gevestig geraak het blyk uit die volgende woorde van Janowitz en Little: 'In time their conviction that the study of military institutions is an essential aspect of university intellectual life, and that it must be developed under conditions which insure professional and academic selfregulation, has become accepted... This countertrend has emerged as the dominant approach. Thus the study of military institutions has been established as a university based topic, distinct from government-conducted research ... and the analysis of the military in the form of teaching and student research has moved more to the center of academic life on university campuses' (1974:19). Lang (1970:9) praat in hierdie verband van die 'takeoff' punt van Militêre Sosiologie gedurende die sestigerjare: 'During the 1960 's military sociology, so it appears, passed its takeoff point'.

Waarskynlik een van die treffendste aanduidings van Janowitz en Little se aanspraak hierbo is die feit dat selfs universitêre navorsingssentra soos die 'Institute for Social Research' by die Universiteit van Michigan - wat gedurende die sestigerjare gekant was teen militêre kontrakte en finansiële bystand vanuit hierdie oord, na die beëindiging van die Vietnam Oorlog en die invoering van ' $n$ vrywilligerweermag ('all-volunteer force') aktief betrokke begin raak het by navorsing oor die sosiale en sosiaal-sielkundige dimensies van militêre mannekrag aangeleenthede soos met betrekking tot die vrywilligersweermag na vore tree (Janowitz en Little, 1974:19). Alhoewel alle spanninge en potensiële spanninge nie deur hierdie veranderde toedrag van sake uit die weg geruim is nie, word hierdeur tog gunstiger omstandighede geskep vir die bevestiging van die Militêre Sosiologie op die outonome weg wat dit pas betree het.

\section{Enkele beperkinge van toepassing op navorsing in die veld van die Militêre Sosiologie}

Navorsingsbehoeftes en -beperkings in die studiegebied van die Militêre Sosiologie moet gesien word teen die agtergrond van die feit dat hierdie studiegebied tot dusver in 'n relatief onontginde staat verkeer het en relatief min aandag in akademiese kringe geniet.

Wat die onontginde aard van die Militêre Sosiologie betref word die grootste duidelikheid verkry deur enkele opmerkings wat in hierdie verband tussen die jare 1955 tot 1977 in die literatuur verskyn het, aan te haal. Van die toestand van die Militêre Sosiologie voor Wêreldoorlog II, sê Hall die volgende: 'American sociologists devoted little attention to military institutions and social aspects of military life until the rapid fullscale mobilization of World War II' (Hall, 1956:59).

Roucek weer, merk die volgende op: 'Although the American scholars have produced some magnificent studies in the field of history of militarism, political geography, and the phenomenon of war in general, strangely enough the field of Military Sociology, although able to point with pride to some outstanding individual contributions as a branch of sociology is relatively unknown and ignored in terms of regular courses (or textbooks) in the higher institutions of learning (a definite index of respectability used by the American professional sociologist). This is probably due to the dangerous American habit of relating military sociology to the concept of war, and war is something so unholy to the American mind that it must be ignored and not studied' (Roucek, 1962:26).

Vanaf die vroeë sewentigerjare begin dit uit soortgelyke opmerkings duidelik word dat die Militêre Sosiologie geleidelik as subgebied van die sosiologie gevestig raak - en inderdaad gevestig behoort te raak - maar dat daar steeds baie ruimte vir verbetering oorbly. In 1970 merk Van Gils die volgende op: 'Uit de beslissing van de redactie van Mens en Maatschappij een nummer aan de militaire sociologie te wijden blijkt wel de groeiende belangstelling voor dit subspecialisme van de sociologie. De noodsaak van deze belangstelling behoeft, gezien de huidige internasionale spanningen, nauweliks meer onderstreept te worden' (1970:392). 
Kourvetaris en Dobratz (1976:67-68 en 94) beskryf die situasie in 1976 soos volg: 'Despite the recent notable increase of social science publications, the appearance of two journals, and the efforts of the Inter-University-Seminar on Armed Forces and Society, we believe the sociology of the military still occupies a marginal and ambivalent position within academic sociology'. Verder sê hulle: 'Overall, while the field has recently made some progress, we still believe that it is underdeveloped and has not achieved widespread acceptance in sociology and the larger academic community. The development of the sociology of the military has been uneven with greater emphasis on the applied aspects of research'.

'n Idee van die relatief min aandag wat die Militêre Sosiologie in akademiese kringe geniet, kan gevorm word deur Kourvetaris en Dobratz (1976:71) se verwysing na twee opnames (1972 en 1974) van nasionale veiligheidsstudies wat gedoen is deur die 'New York University National Security Education Program'. Hierdie opnames vind in 1972 nege voorgraadse en drie nagraadse kursusse in Militêre Sosiologie en in 1974 dertien voordraadse en ses nagraadse kursusse in Militêre Sosiologie in die V.S.A.

'The Guides to graduate Departments of Sociology' wat deur die Amerikaanse Sosiologiese Vereniging gepubliseer word, vestig die aandag op die beperkte aantal universiteite waar Militëre Sosiologie as ' $n$ spesialiseringsgebied vir nagraadse studente aangebied word. In 1969 dui slegs 1 uit 169 departemente aan dat Militêre Sosiologie aangebied word; in 1970 styg die aantal departemente na 4; in 1971-72 dui 4 universiteite aan dat Militêre Sosiologie aangebied word en 'n verdere 11 dui aan dat dit moontlik is vir nagraadse studente om in die Militêre Sosiologie te spesialiseer; in 1972-73 daal hierdie getalle na onderskeidelik 3 en 9. In 1974 word Militêre Sosiologie by slegs 6 uit 215 universiteite genoem en in 1975 ' $n$ totaal van 9 uit 216 (in Kourvetaris en Dobratz, 1976:71-72).

Die enigsins ongunstige posisie van die Militêre Sosiologie as kursus aan universiteite, korreleer baie sterk positief met die volgende toedrag van sake soos uit gidse van die Amerikaanse Sosiologiese Vereniging na vore tree. Byvoorbeeld gedurende 1970 dui 54 uit 8,530 persone aan dat Militêre Sosiologie een van hul twee hoofareas van kundigheid vorm. In 1973-74 is hierdie getalle onderskeidelik 61 uit 7,590 en in
$1975-76$ is die getalle 64 uit 8,915 persone. (in Kourevetaris en Dobratz, 1976:71).

Ook die opname van Jones en Kronus (1975 in Kourvetaris en Dobratz, 1976:71) dui in dieselfde rigting as die hierbogenoemde bevindings. $\mathrm{Na}$ aanleiding van ' $n$ vraag aan ' $n$ toevallig geselekteerde steekproef van volle- assesor- en buitelandse lede van die Amerikaanse Sosiologiese Vereniging dat drie velde van toenemende en drie velde van afnemende belang in die Sosiologie aangedui moet word, blyk 120 persone $(27 \%)$ negatief teenoor die Militêre Sosiologie te wees, slegs $3(1 \%)$ positief en $322(72 \%)$ neutraal.

Ook in die militêre konteks - te wete die Militêre Akademies van die V.S.A. - blyk dit na aanleiding van navrae deur Kourvetaris en Dobratz (1976:72) dat die posisie van die Militêre Sosiologie, soos ook die geval is aan universiteite, marginaal van aard is. Laastens noem Kourvetaris en Dobratz (1976:73) dat daar wel gevalle aan universiteite is waar kursusse verbandhoudend met die Militëre Sosiologie - bv. nasionale veiligheid, siviel-militêre verhoudings ens. - aangebied word, maar in hierdie verband merk hy op: 'We might suggest that while broad and inter-disciplinary perspectives are quite valuable to sociology, the overall effect for the development of sociology of the military per se may be deleterious.

Teen hierdie agtergrond word gelet op enkele navorsingsbehoeftes en navorsingsbeperkings.

Wat die navorsingsbehoeftes van die Militêre Sosiologie betref - dus areas waarop navorsing gekonsentreer kan word - dui Kourvetaris en Dobratz (1976:95) die volgende aan en wel in die lig daarvan dat grootskaalse konvensionele oorloë en massa-weermagte enigsins disfunksioneel word in die kernera. Eerstens dat die Militêre Sosiologie meer indringend aandag moet gee aan nie-konvensionele, kwasi-militêre en para-militêre sosiale groeperinge, bewegings en tipes van oorloë. In hierdie verband verwys hulle na guerrilla oorloë, burger-oorloë, revolusionêre oorloë, terroriste groepe, inligting, bewaking ('surveillance') en politieke sluipmoorde.

Lang (1972:156) dui ook aan dat die nuwe vorme van oorlog-voering - soos die hierbo genoem van toenemede belang word in die studiegebied van die Militêre Sosiologie. Twee verdere terreine waarop hy die aandag vestig is die potensiële bydrae van die Militêre Sosiologie in die 
bestudering van beleidsprobleme en die metodes waardeur vrede gehandhaaf word.

Navorsingsbeperkings - dit wil sê struikelblokke in die weg van sy volle wetenskaplike ontplooiing - waarmee die Militêre Sosiologie gekonfronteer word, is, aan die hand van Kourvetaris en Dobratz (1976:31-32) die volgende:

1. Sedert sy ontstaan het die Militêre Sosiologie 'n toegepaste oriëntasie en konseptuele sofistikasie. Die gevolg is dat talle boeke en artikels van ' $n$ kwalitatiewe aard is en op ' $n$ lae vlak van abstraksie geskryf is.

2. 'n Sterk struktureel-funksionele of te wel konsensus benadering in die meeste geskrifte met gevolglik min aandag aan konflik aspekte en die sisteem-benadering.

3. Ideaal gesproke is die militêre sisteem 'n niepartygenootskaplike instelling maar word normaalweg geassosieer met ' $n$ konserwatiewe ideologie wat skepties staan teenoor sosiale en politieke verandering. Afgesien hiervan oorheers die ideologiese dikwels die teoretiese in die bestudering van die militêre waardeur kennis van die werklikheid uiteraard skade kan ly.

4. Die geslote of semi-geslote aard van militêre instellings skep probleme van toegang tot data veral sover dit kontroversiële aangeleenthede betref.

5. Omdat die Militêre Sosiologie tot dusver gedomineer is deur enkele individue en groepe, is dit moeilik vir jong sosioloë met nuwe of verskillende perspektiewe om aanvaarding te vind.

6. Die interdissiplinêre aard van die bestudering van militêre aangeleenthede maak dit problematies en moeilik om die omvang en inhoud van die studiegebied te bepaal en bemoeilik ook geïntegreerde navorsing, dus waar een studie voortbou op 'n vorige om aldus vooruitgang in sosiologiese teorie teweeg te bring.

7. In navorsingsprojekte wat deur 'n regering geborg word, word die doelwitte en aard van die navorsing dikwels deur belange van die regering bepaal. Hierbenewens is sosioloë in projekte van hierdie aard dikwels lede van ' $n$ span waarin hulle ' $n$ relatief onderhorige posisie beklee en as gevolg waarvan sodanige navorsing dikwels weinigermate deur sosiologiese oorwegings beïnvloed word. In hierdie verband is die indrukke van Michael (1957) verhelderend.

\section{Militêre sosiologie in die RSA en 'n kort toekomsperspektief}

Die enkele opmerkings wat hier oor die Militêre Sosiologie in Suid-Afrika gemaak gaan word, is geensins gebaseer op ' $n$ uitvoerige bestudering van die situasie alhier nie. Dit moet hoogstens beskou word as subjektiewe indrukke wat opgebou is uit informele gesprekke met kollegas en uit die soektog na literatuur met betrekking tot die Militêre Sosiologie.

Die rede vir die behandeling van die Militêre Sosiologie in Suid-Afrika in dieselfde afdeling as die waarin ' $n$ kort toekomsperspektief gegee gaan word, is eenvoudig: Militêre Sosiologie in Suid-Afrika het geen noemenswaardige verlede nie en moet hier as spesialiseringsgebied van die sosiologie, nog die eerste lewenslig aanskou. As sodanig het die Militêre Sosiologie in Suid-Afrika slegs 'n toekoms wat afhangende van verskeie faktore, duister of rooskleurig kan wees.

Sover die kennis van hierdie outeur strek, word daar aan geen universiteit in Suid-Afrika op voorgraadse of nagraadse vlak kursusse in die Militêre Sosiologie aangebied nie. In hierdie verband kan die Randse Afrikaanse Universiteit, wat op honneursvlak ' $n$ sodanige kursus aanbied, uitgesonder word.

Hiermee word egter nie te kenne gegee dat geen universiteit in Suid-Afrika kursusse aanbied wat selfs nou verwant aan die Militêre Sosiologie is nie. In sekerlik die meeste kursusse in die politiek wetenskappe en geskiedenis en ook die politieke sosiologie, geniet die militêre op een of ander wyse die aandag. So sal daar uiteraard ook talle raakpunte tussen die Militêre Sosiologie en die graad B. Mil. wat deur byvoorbeeld die Universiteit van Stellenbosch aangebied word, bestaan.

Hierbenewens is daar ook Institute van Strategiese Studies (aan die RAU bv. en die Universiteit van Pretoria), die afdeling vir die bestudering van Konflik aan die RGN, asook die afdeling van Militêre Navorsing aan die Nasionale Instituut vir Personeelnavorsing wat noodwendigerwys areas nou verwant aan die Militêre Sosiologie sal bestudeer.

Bykomstig hiertoe is die feit dat die Suid-Afrikaanse Weermag interne navorsingsprojekte van ' $n$ sosiaal-sielkundige aard deurvoer, ook van besondere belang. 


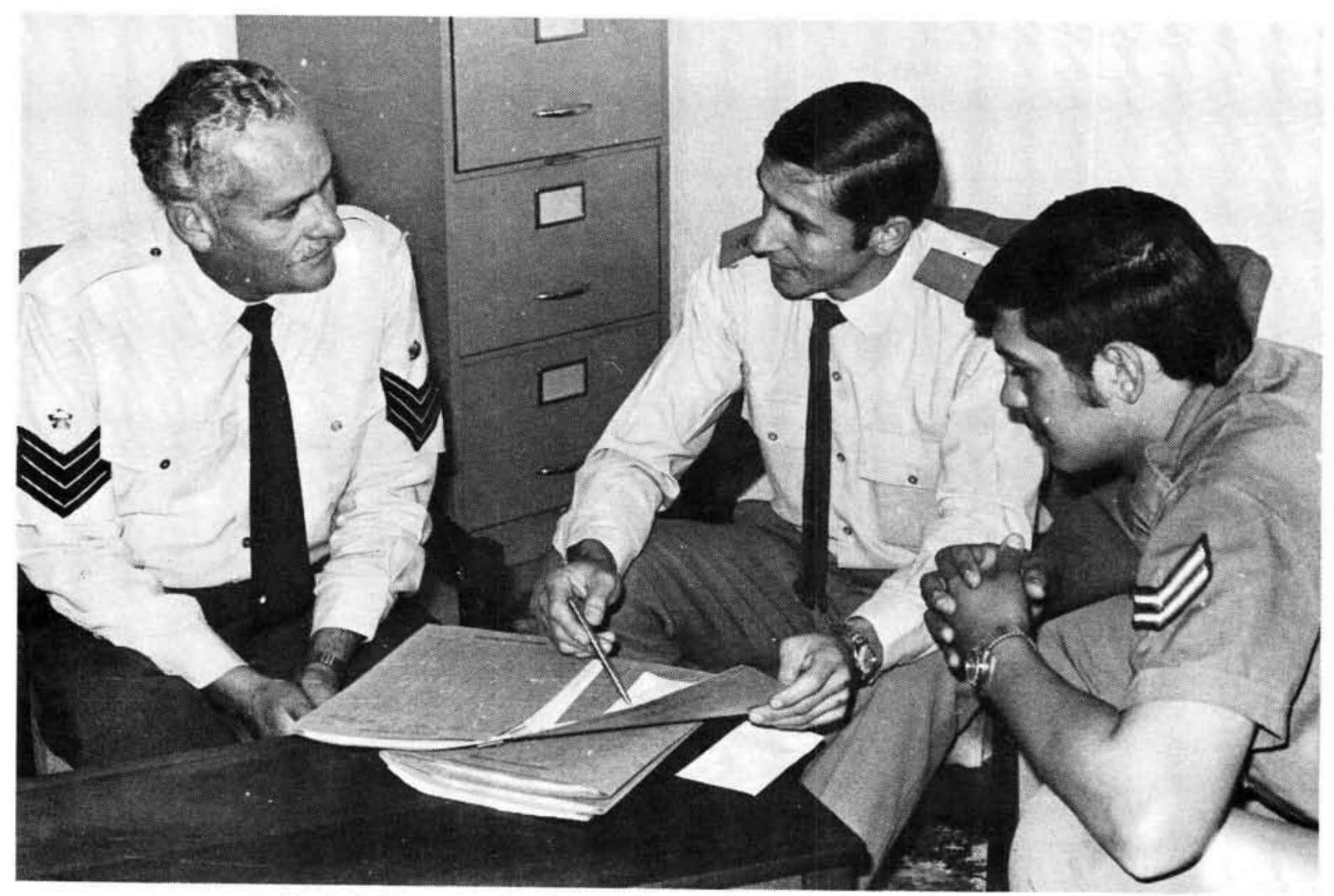

'n Sosiaal-sielkundige besig met die bespreking van 'n probleem

Alles inaggenome, kan dus nie beweer word dat aangeleenthede nou verwant aan die Militêre Sosiologie deur niemand in Suid-Afrika bedink of nagevors word nie. Wat wel die geval is, is dat Militêre Sosiologie as 'n outonome subarea van die sosiologie nog nie in Suid-Afrika bestaan nie en 'n besondere poging nodig sal wees om dit as sodanig te vestig.

Vervolgens word kortliks verwys na enkele geskrifte in Suid-Afrika wat as nou verwant aan die Militêre Sosiologie beskryf sou kon word. Dit sluit in vier magister-verhandelinge wat gedurende die afgelope dertien jaar verskyn het asook ' $n$ vaktydskrif:

In 1967 voltooi N.J. Mouton sy magister-verhandeling, getiteld: Die Mens se Houding Teenoor Oorlog in die departement Sielkunde aan die Universteit van Pretoria.

Vier jaar later, in 1971, dien A.W. van den Aardweg sy MA-verhandeling, getiteld: The Origin Development and Field of Military Sociology by die departement Sosiologie van die Universiteit van Pretoria in. Hierdie is waarskynlik tot dusver die eerste en enigste verhandeling in Suid-Afrika wat oorwegend en eksplisiet oor die Militêre Sosiologie handel.
E. Harrington dien in 1973 sy MA-verhandeling, getiteld: 'n Sosiologiese studie van die funksies van kerkbesoek in die Ned. Geref. Kerk volgens die klassifikasie van R.K. Merton met spesiale verwysing na diespligtiges in die Suid-Afrikaanse Weermag by die departement Sosiologie van die Potchefstroomse Universiteit in.

Ten slotte dien die magister-verhandeling van E.F.C. Wehrmann wat hy in 1975 by die departement Sosiologie van die Universiteit van Pretoria inhandig, ook hier genoem te word. Dit is getiteld: 'n Verkennende Sosiologiese Ondersoek na Dienspligtiges se Beskouing van Jeugleierskap.

Interessant is dit om daarop te let dat al drie laasgenoemde verhandelings geskryf is deur Staandemaglede van die Suid-Afrikaanse Weer$\operatorname{mag}^{12}$.

Ten opsigte van huidige navorsing op nagraadse vlak in die Militêre Sosiologie wat huidiglik in Suid-Afrika aan die gang is, kan hier net genoem word dat daar na die beste wete van die outeur tans twee studies op doktorale vlak aan die gang is - te wete ' $n$ studie waarmee hierdie outeur aan die Randse Afrikaanse Universiteit 
besig is en ' $n$ ander wat aan die Universiteit van Pretoria gedoen word.

Laastens wat betref die Militêre Sosiologie in Suid-Afrika is dit nodig om daarop te wys dat die Suid-Afrikaanse Weermag ' $n$ amptelike vaktydskrif getiteld 'Militaria' vanaf ongeveer 1969 die lig laat sien waarin ook van tyd tot tyd artikels verskyn wat vir die Militêre Sosiologie van belang is.

Wat die toekomstige ontwikkeling van die Militêre Sosiologie betref, beklemtoon Kourvetaris en Dobratz (1976:96-97) enkele aspekte wat vir die Militêre Sosiologie in die algemeen en waarskynlik in mindere of meerdere mate vir die Militêre Sosiologie in Suid-Afrika ook geld:

1. Militêre Sosiologie sal waarskynlik steeds gebuk gaan onder weerstand van meer liberale akademiese dissiplines en subareas van die sosiologie voordat dit as studiegebied met wetenskaplike bestaansreg aanvaar sal word.

2. In daardie gevalle waar die Militêre Sosiologie nie ' $n$ bestaansreg in universitêre konteks gegun word nie, word die uitnodiging geskep vir regeringsgesteunde navorsingsprojekte. Onder hierdie omstandighede sal die neiging tot toegepaste navorsing voortgeset wees en belowende jong sosioloë nie geneigd wees om die Militêre Sosiologie as spesialiseringsgebied te kies nie.

3. Militêre Sosiologie sal waarskynlik daardie persone aantrek wat vorige ondervinding van die militêre opset het of 'n konserwatiewe oriëntasie openbaar.

Kourvetaris en Dobratz (1976:96-97) sluit die enigsins sombere prentjie van die posisie van die Militêre Sosiologie af op 'n positiewe noot: 'In conclusion, some encouraging signs are also present for the development of sociology of the military. It originally made important contributions to small group research and influenced prevailing theories of social psychology and the development of reference group theory. The recent resurgence of publications in the area, initiation of two new journals and the work of various organisations have also contributed to the field and promoted some sense of respectability. for the study of the military. But in spite of these efforts, one can only speak of a partial legitimation and institutionalization of sociology of the military vis-a-vis other areas of sociology which have enjoyed acceptances within academia'.
Die belangrikste enkele oorweging wat die bestaan van 'n dinamiese Militêre Sosiologie in die RSA regverdig is die oorlewingsstryd waarin hierdie land hom bevind en die gevolglike noodsaaklikheid dat alle moontlike kennis wat hierdie stryd kan laat slaag ten volle ge-eksploiteer moet word.

- Mnr A. Senekal is verbonde aan die Dept Sosiologie van die Randse Afrikaanse Universiteit.

\section{Bibliografie}

Coates, C.H. \& Pellengrin, R.J.: Military Sociology: A Study of American Military Institutions and Military Life. The Social Science Press, University Park, 1965.

Dressler, D.: Sociology: The Study of Human Interaction. Alfred Knopt, New York, 1969.

Hall, R.L.: 'Military Sociology 1945-55' in Sociology in the United States of American: A Trend Report. Unesca, Paris 1956.

Hutchinson, C.E.: 'The Meaning of Military Sociology': Sociology and Social Research. Vol. 41, 1956-1957, pp. 427-433.

Janowitz, M. \& Little, R.W.: Sociology and the Military Establishment. Sage Publications, Beverly Hills, 1974.

Kourvetaris, G.A. \& Dobratz, B.A.: 'The Present State of Development of Sociology of the Military': Journal of Political \& Military Sociology. Vol. 4, №. 1, 1976, pp. 67-105.

Lang, K.: 'Military Sociology: A Trend Report and Bibliography': Current Sociology. Vol. 13, №. 1, 1965, pp. 1-55.

Lang, K.: Military Sociology 1963-1969: A Trend Report and Bibliography. Mouton \& Co., The Hague, 1970.

Lang. K.: Military Institutions and the Sociology of War. Sage Publications, Beverly Hills, 1972.

Michael, D.N.: 'Some Factors Tending to Limit the Utility of the Social Scientist in Military Systems Analysis': Operations Research. Vol. 5, No. 1. 1957, pp. $90-96$

Roucek, J.S.: "The Trends in American Military Sociology and Its Educational Implications': Duquesne Review. Vol. 8, No. 1, 1962, pp. 26-49.

Roucek, J.S. \& Lottich, K.V.: 'American Military Sociology: The American Military Mind': Social Science Information. Vol. 3, No. 1, 1964, pp. $91-106$.

Van Den Aardweg, A.W.: The Origin, Development and Field of Military Sociology. Ongepubliseerde M.A. -Verhandeling, U.P., 1971.

Van Doorn, J.: Armed Forces and Society, Mouton, The Hague, 1968.

Van Gils, M.R.: 'Militaire Sociologie: Ter Inleiding': Mens \& Maatschappij. Vol. 45, No. 6, Nov - Des 1970, pp. 393-408.

Walter, P.: 'Military Sociology' in Roucek, J.S.: Contemporary Sociology, Philosophical Library, New York, 1958.

\section{Voetnotas}

1. In hierdie verband kan verwys word na die werk van $P$. Valkenburgh, 'Naar een Sociologische Teorie van Oorlog' in Sociologische Gids, Vol. 9, 1962, pp. 178-192 as voorbeeld van 'n poging binne die konteks van die Sosiologie van Oorlog om riglyne vir die ontwikkeling van 'n sosiologiese teorie ter verklaring van die verskynsel van oorlog op te stel. Enkele verdere studies wat in hierdie kategorie val, dien hier genoem te word: Die studie van F. van Heek, 'The Sociological Aspects of War' in International Journal of Comparative Sociology, Vol. 5, No. 1, 1964, pp. 25-39; die werk van Aaron Noland, 'Proudhon's Sociology of War' in American Journal of Economics and Sociology, Vol. 29, No. 3, 1970, pp. 289-304; Quincy Wright, A Study of War, University of Chicago Press, 1942, Willard Waller, War in the Twentieth Century, The Dryden press, New York, 1940; Frank. M. Russel, Theories of International Relations, Appleton-Century-Crofts, New York, 1936; M. Ginsberg, 'The causes of War', Sociological Review, Vol. XXXI, No. 2. 1939, pp. 121-143.

2. Hier word baie kortliks op enkele sake om en by WO I gewys wat, vanweë die feit dat die militêre daarin aandag geniet, nie heeltemal los te sien is van die ontstaan van Militêre Sosiologie gedurende WO II nie en ook nie van die toenemend interdissiplinêre aard van werksaamhede op hierdie studiegebied nie. Die 
eerste saak is die feit dat sielkundiges gedurende WO I betrokke was by intelligensietoetsing en personeelseleksie en gedurende WO II 'n wyer veld van onderwerpe gedek het sodat militêre sielkunde na WO II 'n redelik gevestigde spesialiseringsgebied was. ' $n$ Tweede saak is die feit dat 'n handjievol politieke wetenskaplikes 'n nuwe akademiese belangstelling in die militêre vertoon deur hul bestudering van oorlog en siviel-militêre verhoudings. Hierdie pogings is geïnisieer deur veral lede van die Chicago realistiese skool van politiek te wete Quincy Wright, Harold D. Lasswell, en Hans Speier, 'n Duitse immigrant, en een van die eerstes in die VSA om oor militêre instellings te skryf (Janowitz en Little, 1974:11).

3. Die 'Research Branch' word in verskillende bronne verskillend benaam. Soos Coates en Pellengrin verwys Hall in hierdie verband na die 'Research Branch' (1956:50) terwyl Hutchinson praat van die 'Troop Attitude Research Program' (1956-57:429) en Kourvetaris en Dobratz die benaming 'The Troop Research Program' (1976:68) gebruik. Klaarblyklik het hierdie verskillende benamings op presies dieselfde instansie betrekking maar in die lig daarvan dat Coates 'n voormalige kolonel in die weermag van die VSA is, word aanvaar dat sy benaming waarskynlik die mees akkurate is en word derhalwe deurgaans daarvan gebruikgemaak.

4. Interessant is dit om hier daarop te let dat hierdie ook die eerste geleentheid verteenwoordig waarby sosioloë eksplisiet as sosioloë, deur enige tak van die regering van die VSA in diens geneem is (Lang, 1965:3).

5. ' $n$ Verdere en besonder belangrike werk van Janowitz wat min of meer dieselfde tyd verskyn het $\mathrm{nl}$. The Professional Soldier. The Free Press, New York, 1960 beskryf die ontwikkeling van die Amerikaanse militêre gedurende die eerste helfte van hierdie eeu, in terme van die volgende: 'n sosiale en politieke profiel. die professionele lewe, organisatoriese opset, en leierskap (Kourvetaris en Dobratz. 1976:70).

6. Kourvetaris en Dobratz stel dit dat die Inter-University Seminar on Armed Forces and Society in 1961 onder voorsitterskap van Morris Janowitz $\mathrm{n}$ met die bystand van die Russel Sage Foundation gestig is.

7. Hierdie Werkgroep, wat voorheen as die Sub-komitee van die komitee van Politieke Sosiologie bekend gestaan het, bestaan uit Sosioloë vanoor die hele wêreld wat betrokke is by navorsing oor militêre organisasie en die militêre professie, die sosiologie van oorlog en revolusie, die optredes van militêre regimes en die sosiologiese aspekte van ontwapening, wapenbeheer en ontwapening. Die uitvoerende komitee van die Werkgroep bestaan uit Bengt Abrahamsson, Universiteit van Stockholm, Swede; Dario Canon, Instituto Torcuato di Tella. Argentinië, Jacques van Doorn, Nederlandsche Economische Hoogeschool, Nederland; John A. Jacson. Universiteit van Oos Anglia, Vere- nigde Koningkryk; Ali Mazrui, Makerere kollege, Uganda; David N. Solomon, McGill Universiteit, Kanada; Jerzy Wiatr, Poolse Akademie vir Wetenskap, Poland; P. Zhilin, Instituut van Militêre Geskiedenis, Moskou, USSR met Morris Janowitz as voorsitter (Lang, 1970:5).

8. Uit die London 1964 konferensie vloei 'n spesiale uitgawe van die European Journal of Sociology Vol. 6, No. 2, 1965 met die volgende as tema: 'Armed Forces and Society in Western Europe". 'n Spesiale vergadering gehou in London 1967 lewer die volgende publikasie met Jacques van Doorn as redakteur op : Military Professions and Military Regimes, Mouton, The Hague, 1969. Die 1966 Evian konferensie in Frankryk, vind neerslag in 'n publikasie, ook met Jaques van Doorn as redakteur, getiteld: Armed Forces and Society, Mouton, The Hague, 1968 (Lang, 1970: $5-6$ ). Na aanleiding van die werk van hierdie Werkgroep -sien 'n verdere publikasie in 1971 die lig: Morris Janowitz en Jacques van Doorn: On Military Intervention, On Military Ideo/ogy, Rotterdam University Press, Rotterdam, 1971 (Janowitz en Little, 1974:23)

9. In hierdie verband kan die volgende genoem word: The New Military, Russel Sage Foundation, New York, 1964, red. Janowitz, M.; Public Opinion and the Military Establishment, Sage Publication, Beverly Hills, 1971, red. Moskos, C.C.; The Military Industrial Complex, Sage Publications, Beverly Hills, California, 1972, red. Sarkesian, S.C.; Military Rule in Latin America, Sage Publications, Beverly Hills, California, 1973, red. Scmitter, P.: Political Military Systems, Sage Publications, Beverly Hills, California, 1974, red. Kelleher, C.M. (Kourvetaris en Dobratz, 1976:70).

10. Voorbeelde hiervan is die volgende: Lang, K.: 'Military Sociology: A trend Report and Bibliography', Current Sociology Vol. 13, No. 1, 1965, p. 1-55; Van Doorn, J.: 'Militärische und Industrielle Organisation: ein Soziologischer Vergleich' in: Matthes, J., ed. Soziologie und Gesellschaft in den Niederlanden, Luchterhand, Neuwied/Rhein und Berlin, 1965; Janowitz, M.: 'The Military Establishment: Organization and Disorganization' in: Merton, R.K. en Nisbet, R.A., eds. Contemporary Social Problems, Harcourt, Brace and World New York, 1966; Horowitz, I.L.: 'The Military Elites' in: Lipset, S.M. en Solari, A., eds. Elites in Latin America, Oxford University Press, New York, 1967; Roghmann, K. en Ziegler, R.: 'Militärsoziologie' in König, R., ed. Handbuch der empirischen Sozialforschung, II. Band. Ferdinand Enke Verlag, Stuttgart, 1969 (Lang, 1970:10).

11. 'Armed Forces and Society in Western Europe'. Archives européennes de sociology, Vol. 6, No. 2, 1965:223-308 en König et. al., ed. 'Beiträge Zur Militärsoziologie'. Kölnerzeitschrift fur Soziologie und Sozialpsychologie. Sonderheft 12 1968:1-360 (Lang, 1970:10).

12. Hierdie lys sluit natuurlik verhandelings en proefskrifte wat aan een of ander vertroulikheidsbepaling onderhewig is, uit. 